\title{
The Escherichia coli GcvB sRNA Uses Genetic Redundancy to Control cycA Expression
}

\author{
Lorraine T. Stauffer and George V. Stauffer \\ Department of Microbiology, University of Iowa, Iowa City, IA 52242, USA \\ Correspondence should be addressed to George V. Stauffer, george-stauffer@uiowa.edu
}

Received 25 February 2012; Accepted 19 March 2012

Academic Editors: H. Asakura, P. D. Ghiringhelli, G. Koraimann, F. Navarro-Garcia, J. Theron, and K. Trulzsch

Copyright ( $) 2012$ L. T. Stauffer and G. V. Stauffer. This is an open access article distributed under the Creative Commons Attribution License, which permits unrestricted use, distribution, and reproduction in any medium, provided the original work is properly cited.

\begin{abstract}
The Escherichia coli sRNA GcvB regulates several genes involved in transport of amino acids and peptides (sstT, oppA, $d p p A$, and $c y c A$ ). Two regions of GcvB from $n t+124$ to +161 and from $n t+73$ to +82 are complementary with essentially the same region of the $c y c A$ mRNA. Transcriptional fusions of $c y c A$ to $l a c Z$ showed the region of $c y c A$ mRNA that can pair with either region of $\mathrm{GcvB}$ is necessary for regulation by GcvB. However, mutations in either region of $g c v B$ predicted to disrupt pairing between $c y c A$ mRNA and GcvB did not alter expression of a $c y c A$-lacZ translational fusion. A genetic analysis identified nts in GcvB necessary for regulation of the $c y c A-l a c Z$ fusion. The results show that either region of GcvB complementary to $c y c A$ mRNA can basepair with and independently repress $c y c A-l a c Z$ and both regions need to be changed to cause a significant loss of repression.
\end{abstract}

\section{Introduction}

The E. coli $g c v B$ gene encodes a sRNA of 206 nts [1]. Transcription of $g c v B$ is activated by GcvA when cellular glycine is high and repressed by GcvA when glycine is limiting; repression by GcvA requires the accessory GcvR protein [1]. $\mathrm{GcvB}$ regulates $c y c A$, encoding the glycine transport protein [2]. Thus, GcvB regulates its own synthesis by controlling the level of glycine transported into the cell. A $\Delta g c v B$ strain shows constitutive synthesis of OppA and DppA, the periplasmic binding protein components of the two major peptide transport systems, SstT, a serine transport system, and CycA, a glycine transport system [1-4]. The Salmonella enterica serovar Typhimurium GcvB also regulates OppA and DppA levels and several other genes involved in transport of polar and branched amino acids and general amino acid metabolism $[5,6]$.

Evidence suggests GcvB regulates its target mRNAs by an antisense mechanism, basepairing with the mRNAs to prevent translation initiation [3-6]. Although it is unclear how extensive pairing between a sRNA and a mRNA must be, research indicates one or two regions of 8-9 basepairs is sufficient for regulation [7]. In cases where basepairing interactions occur, the RNA chaperone $\mathrm{Hfq}$ is required, likely to alter RNA secondary structures or to bring together sRNAs and target mRNAs, increasing local RNA concentrations [811]. Hfq binds GcvB [11, 12], stabilizing the RNA [5, 13], and loss of Hfq results in the loss of repression of GcvB target mRNAs $[2,4,5,13]$. For sRNAs studied in detail that regulate by an antisense mechanism, often a single basepair change in the sRNA or its target mRNA results in a loss of regulation by the sRNA (e.g., the sRNA SgrS and its target $p t s G$ mRNA [14]). For GcvB, however, it is surprising that most changes predicted to disrupt pairing with regions of the target mRNAs have little or no effect on GcvB's ability to regulate [2-4].

GcvB homologs contain two conserved sequences of 13 nts (Con-I) and $10 \mathrm{nts}$ (Con-II) (Figure 1(a)) [1, 3, 5]. In addition, a G/T-rich domain that includes the Con-I sequence was shown to be essential for interaction with most GcvB target mRNAs in E. coli and S. enterica $[4,5,13]$. In S. enterica, the Con-II region also pairs with $c y c A$ mRNA, possibly inhibiting translation initiation [6]. Analysis of $E$. coli GcvB identified two regions from nt +73 to +82 and from $\mathrm{nt}+124$ to +161 complementary to $c y c A$ mRNA (Figures 1(b) and $1(\mathrm{c}))$. The region from +73 to +82 overlaps Con-I and 
the G/T-rich domain, and the region from +124 to +161 overlaps Con-II (Figure 1(a)). In addition, transcriptional fusions of $c y c A$ to $l a c Z$ verified the region from -8 to -26 upstream of the AUG start codon, and complementary with both the +73 to +82 and +124 to +161 regions of $\mathrm{GcvB}$ is required for regulation of $c y c A$ (Figures $1(\mathrm{~b})$ and $1(\mathrm{c})$ ) [2]. However, changes in either region of GcvB independently did not alter regulation of $c y c A-l a c Z$ [2]. We devised a genetic selection to identify any nts in $G \mathrm{cvB}$ required to regulate $c y c A$-lacZ. In this study, we show the region of GcvB from +73 to +82 as well from nt +124 to +161 is important for regulation of a $c y c A-l a c Z$ fusion. In addition, both regions can independently repress, suggesting $\mathrm{GcvB}$ regulates $c y c A$ lac $Z$ by a mechanism that uses redundancy within GcvB.

\section{Materials and Methods}

2.1. Bacterial Strains, Plasmids, and Phage. The E. coli strains, plasmids, and phage used are listed in Table 1 or are described in the text.

2.2. Media. The complex medium used was Luria-Bertani broth (LB) [19]. Agar was added at 1.5\% (w/v) to make solid medium. The defined medium used was the salts of Vogel and Bonner [20] supplemented with $0.4 \%(\mathrm{w} / \mathrm{v})$ glucose (GM). Ampicillin (Amp) was added at $50 \mu \mathrm{g} \mathrm{mL}^{-1}$. X-gal was added at $40 \mu \mathrm{g} \mathrm{m}^{-1}$.

2.3. DNA Manipulation. Plasmid DNA was isolated using a QIAprep Spin Miniprep Kit (Qiagen, Santa Clara, CA). Vent DNA polymerase, Taq DNA polymerase, and restriction enzymes were from New England Biolabs, Inc. (Beverly, MA). T4 DNA ligase was from Roche Diagnostics (Indianapolis, IN). Reactions were as described by the manufacturers.

2.4. Enzyme Assay. $\beta$-Galactosidase assays were performed on mid-log phase cells $\left(\mathrm{OD}_{600} \sim 0.5\right)$ using the chloroform/SDS lysis procedure [19]. Results are the averages of two or more assays with each sample done in triplicate. Results were analyzed using the Student's $t$-test.

2.5. Random and Site-Directed Mutagenesis of $g c v B$. Plasmid pGS634 carries the $g c v B^{+142 C A+159 C C}$ allele on an EcoRIHindIII fragment [2]. Using pGS634 as template, errorprone PCR was used [21] to amplify DNA containing $g c v B$. The upstream primer (GcvB-For) was $5^{\prime}$-CTAGGCGGAATTCGCGGTGGTAATCGTTTAGACATGGC with an EcoRI site (underlined) and hybridizes 50 bps upstream of the $g c v B$ transcription start site. The downstream primer (GcvB-Rev) was 5'-GGGGAAGCTTGAAAGAGATGGTCGAACTGG with a HindIII site (underlined) and hybridizes to pGS634 beginning 44 bps after the $g c v B$ transcription stop site. The $423 \mathrm{bp}$ amplified DNA fragment was digested with EcoRI + HindIII, cloned into EcoRI-HindIII digested and gelpurified vector pGS341 [17], replacing the WT $g c v A$ gene, and transformed into the $\Delta g c v B$ strain GS1144 lysogenized with $\lambda c y c$ A-lacZ. After 1 round of Amp counterselection
[19], cells were plated on LB plates + Amp + X-gal. Killing nontransformed lysogens made identification of darker blue colonies efficient. Plasmid DNA was prepared from potential mutants (dark blue transformants) and the DNA sequenced at the Core Facility at the University of Iowa to verify mutations.

Site-directed mutagenesis of $g c v B$ was performed using the PCR "megaprimer" procedure [22] with pGS594 $\left(\mathrm{p} g c v B^{+}\right)$as template. Changes were verified by DNA sequence analysis and are predicted by the mfold program $[23,24]$ to leave the GcvB secondary structure intact.

2.6. Construction of the $g c v B^{t 1 \dagger}$ Allele and $g c v B^{t 1 \dagger}$ Allele + Additional Mutations. The $g c v B^{\text {t1 }}$ allele with bp changes that make a strong transcription terminator at $\mathrm{t} 1$ and removes sequence distal to tl was constructed using $\mathrm{p} g c v B^{+}$as template and upstream primer GcvB-For and downstream primer GcvB-t1 $\uparrow$ 5'-GGGGAAGCTTGAAAAAAAAGGTAGCCGAATTAGCGGCTACCATGGTCTGAATCGCAG with a HindIII site (underlined) and that hybridizes beginning at bp +135 in $g c v B$. The amplified DNA was digested with EcoRI + HindIII, cloned into EcoRI-HindIII digested and gel-purified vector pGS341, replacing the WT $g c v A$ gene. Base changes were verified by DNA sequence analysis and the plasmid-designated pGS642 $\left(\mathrm{p} g c v B^{\mathrm{t} 1 \uparrow}\right)$ (Figure 2(a)). Mutations in $g c v B$ were then combined with the $g c v B^{\text {t1 }}$ allele by PCR. Plasmids

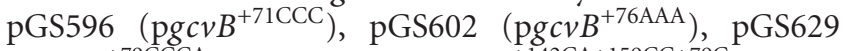
$\left(\mathrm{p} g c v B^{+79 C C C A}\right), \quad$ GGS644 $\left(\mathrm{p} g c v B^{+142 \mathrm{CA}+159 \mathrm{CC}+79 \mathrm{C})}\right.$, and pGS645 ( $\mathrm{p} g c v B^{+142 \mathrm{CA}+159 \mathrm{CC}+80 \mathrm{~A})}$ were used as templates with upstream primer GcvB-For and downstream primer GcvB-t $1 \uparrow$. The amplified DNA fragments were cloned as described for the $\operatorname{pgcvB} B^{\mathrm{t} 1 t}$ allele. Changes were verified by DNA sequence analysis. The plasmids were designated pGS647 $\left(\mathrm{p} g c v B^{\mathrm{t} 1 \uparrow+71 \mathrm{CCC}}\right)$, pGS649 $\left(\mathrm{p} g c v B^{\mathrm{t} 11+76 \mathrm{AAA}}\right)$, pGS653 $\left(\mathrm{p} g c v B^{\mathrm{t} 11+79 \mathrm{CCCA}}\right), \mathrm{pGS655}\left(\mathrm{p} g c v B^{\mathrm{t1} 1+79 \mathrm{C}}\right)$, and pGS656 $\left(\mathrm{pgcv} B^{\mathrm{t} 1 \uparrow+80 \mathrm{~A}}\right)$, respectively (Figure 1$)$.

2.7. Construction of the $g c v B^{\Delta+74: 82}$ Allele and $g c v B^{\Delta+74: 82}$ Allele + Additional Mutations. The $g c v B^{\Delta+74: 82}$ allele with a deletion from bp +74 to +82 was constructed using the PCR "megaprimer" procedure [22]. The new plasmid was designated pGS680 (pgcvB $\left.B^{\Delta+74: 82}\right)$ (Figures 1(a) and 1(c)). Base changes were verified by DNA sequence analysis. Mutations in $g c v B$ in the +124 to +161 region were then combined with the $\operatorname{gcvB} B^{\Delta+74: 82}$ allele by the PCR "megaprimer" procedure [22]. The new plasmids were designated pGS682 $\left(\mathrm{pgcvB} B^{\Delta+74: 82+142 \mathrm{CA}}\right), \mathrm{pGS683}\left(\mathrm{pgcvB} B^{\Delta+74: 82+159 \mathrm{CC}}\right), \mathrm{pGS684}$

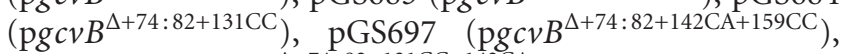

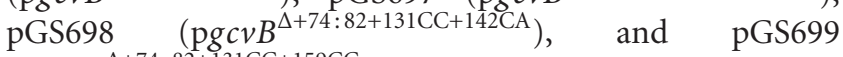
$\left(\mathrm{pgcvB} B^{\Delta+74: 82+131 \mathrm{CC}+159 \mathrm{CC}}\right)$ (Figure 1).

2.8. Construction of $\lambda c y c A^{-24 G G}$-lacZ, $\lambda c y c A^{-29 G}$-lacZ, and $\lambda c y c A^{-30 T}$-lacZ Mutations. Plasmid pcycA-lac $Z$ carries an $E$. coli cycA-lacZ translational fusion [2]. Using pcycA-lacZ as template, PCR "megaprimer" mutagenesis [22] was used to create changes in cycA-lacZ (Figures 1(b) and 1(c)). Base 


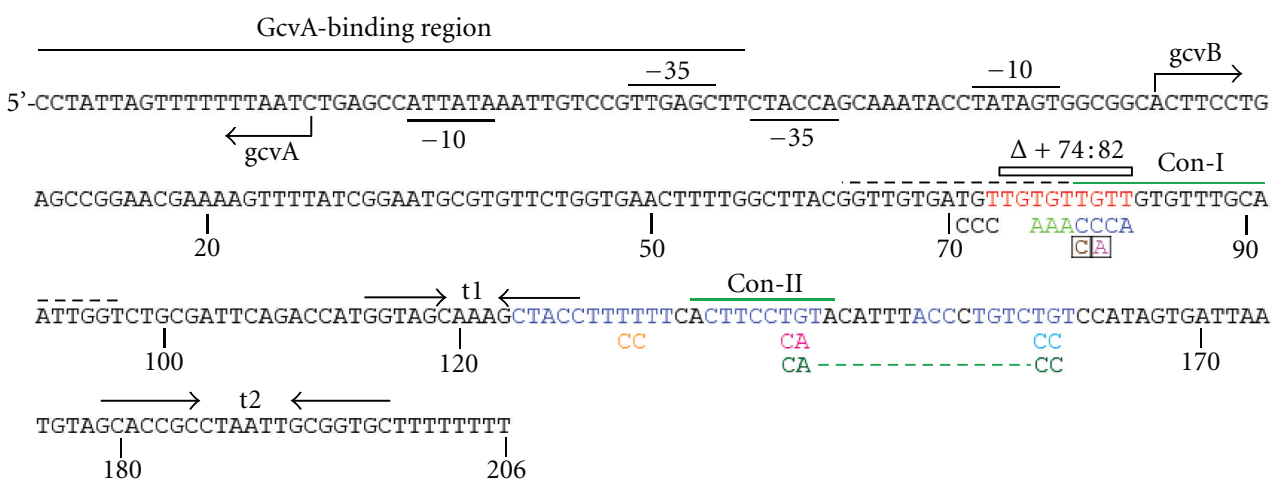

(a)

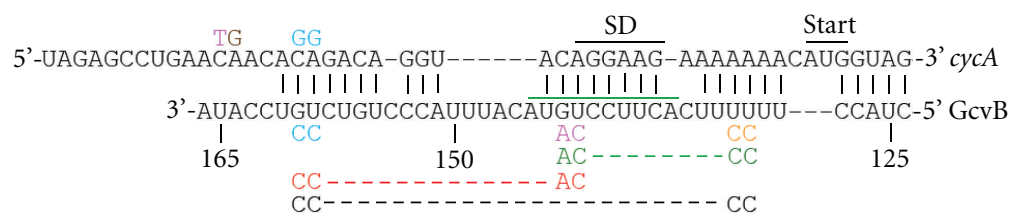

(b)

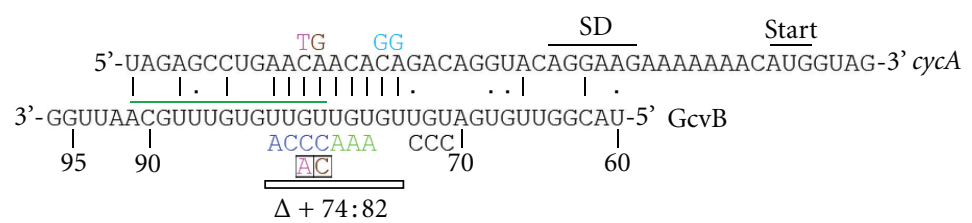

(c)

Figure 1: (a) The $g c v A / g c v B$ promoter region and $g c v B$ gene. Promoter -35 and -10 elements are underlined for $g c v A$ and overlined for $g c v B$ $[1,15]$. The GcvA-binding site is indicated by a line [16]. Inverted arrows show stem-loop sequences of putative transcription terminator t1 and terminator t2. A 13 base and a 10 base conserved sequence in $g c v B$ homologs are designated Con-I and Con-II (green bars) [1, 3, 5]. Con-I is part of a larger G/T-rich domain (dashed line) essential for interaction of GcvB with most characterized target mRNAs [4, 5, 13]. Bases in GcvB complementary with $c y c A$ mRNA in the +73 to +82 region are in red and in the +124 to +161 region in blue. Changes in $g c v B$ shown not to alter $c y c A$-lacZ expression are below the sequence and are color coded [2]. Two independent changes isolated using $\mathrm{p} g c v B^{+142 \mathrm{CA}+159 \mathrm{CC}}$ as template and that result in loss of GcvB repression of $c y c A-l a c Z$ are boxed. (b) Comparison of GcvB from nt +124 to +166 with $c y c A$ mRNA. (c) Comparison of GcvB from nt +60 to +96 with $c y c A$ mRNA. For (b) and (c), complementarity is indicated with lines and GU bps with dots. Changes in $g c v B$ are shown below the sequences, and changes in $c y c A$ are shown above the sequences and are color coded (see text for details).

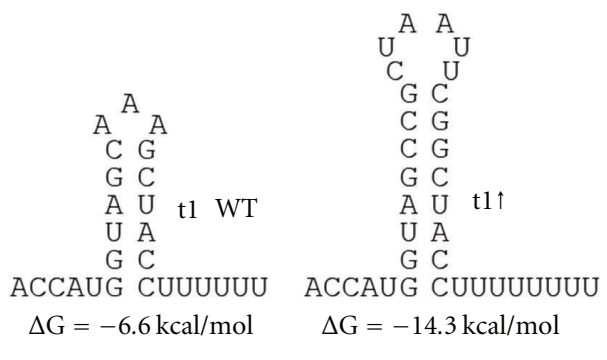

(a)

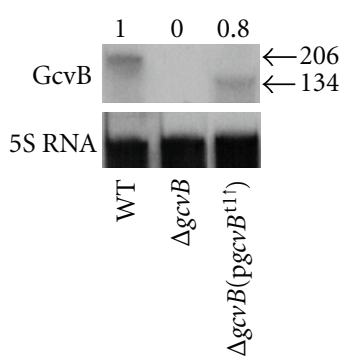

(b)

FIgURE 2: (a) WT terminator $\mathrm{t} 1$ and changes in $\mathrm{t} 1$ predicted to increase $(\uparrow)$ transcription termination. Primers used to construct the $\mathrm{t} 1 \uparrow$ allele delete the sequence distal to the $\mathrm{t} 1 \uparrow$ changes. (b) Northern analysis of GcvB. RNA was isolated from WT, $\Delta g c v B$, or $\Delta g c v B$ transformed with a single-copy plasmid carrying the $g c v B^{\text {tl }}$ allele and probed with either a DIG-labeled GcvB or $5 S$ rRNA-specific DNA probe. Numbers above each lane indicate levels of GcvB relative to WT. 
TABLE 1: Strains, plasmids, and phage.

\begin{tabular}{|c|c|c|}
\hline $\begin{array}{l}\text { Strains*, plasmids, and } \\
\text { phage }\end{array}$ & Relevant genotype & Source or reference \\
\hline \multicolumn{3}{|l|}{ Strains } \\
\hline GS162 & WT & This lab \\
\hline GS1144 & $\Delta g c v B$ & [3] \\
\hline GS1148 & $\Delta h f q$ & {$[13]$} \\
\hline \multicolumn{3}{|l|}{ Plasmids } \\
\hline pGS341 & Single-copy vector + WT gcvA & {$[17]$} \\
\hline pGS594 & Single-copy vector $+\mathrm{WT} g c v B$ & This lab \\
\hline pGS596 & $\begin{array}{l}\text { pGS594 with a -TGT- to -CCC- change of bps }+71 \text { to }+73 \text { in } \\
g c v B\left(\operatorname{pgcv} B^{+71 C C C}\right)^{* *}\end{array}$ & {$[3]$} \\
\hline pGS602 & $\begin{array}{l}\text { pGS594 with a -TGT- to -AAA- change of bps }+76 \text { to }+78 \text { in } \\
g c v B\left(\mathrm{p} g c v B^{+76 A A A}\right)\end{array}$ & {$[3]$} \\
\hline pGS629 & $\begin{array}{l}\text { pGS594 with a -TGTT- to -CCCA- change of bps }+79 \text { to }+82 \\
\text { in } g c v B\left(p g c v B^{+79 C C C A}\right)\end{array}$ & {$[4]$} \\
\hline pGS634 & $\begin{array}{l}\text { pGS594 with a -TG- to -CA- change of bps }+142 \text { and }+143 \\
\text { and a -TG- to -CC- change of bps }+159 \text { and }+160 \text { in } g c v B \\
(\mathrm{pgcvB}+142 \mathrm{CA}+159 \mathrm{CC})\end{array}$ & {$[2]$} \\
\hline pGS642 & $\begin{array}{l}\text { Single-copy vector }+g c v B^{\mathrm{t} 1 \dagger} \text { allele (see Figure } 2 \text { for bp } \\
\text { changes) }\left(\operatorname{pgcv} B^{\mathrm{t} 1 \dagger}\right)\end{array}$ & This study \\
\hline pGS644 & 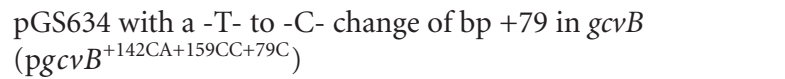 & This study \\
\hline pGS645 & $\begin{array}{l}\text { pGS634 with a -G- to -A- change of bp }+80 \text { in } g c v B \\
\left(\mathrm{p} g c v B^{+142 C A+159 C C+80 A}\right)\end{array}$ & This study \\
\hline pGS647 & $\begin{array}{l}\text { pGS642 with -TGT- to -CCC- change of bps }+71 \text { to }+73 \text { in } \\
g c v B\left(\text { p } g c v B^{\text {t1 } 1+71 C C C}\right)\end{array}$ & This study \\
\hline pGS649 & $\begin{array}{l}\text { pGS642 with a -TGT- to -AAA- change of bps }+76 \text { to }+78 \text { in } \\
g c v B\left(p g c v B^{\text {t11+76AAA }}\right)\end{array}$ & This study \\
\hline pGS653 & $\begin{array}{l}\text { pGS642 with a -TGTT- to -CCCA- change of bps }+79 \text { to }+82 \\
\text { in } g_{c v} B\left(\operatorname{pgcv} B^{\text {t1 } 1+79 C C C A}\right)\end{array}$ & This study \\
\hline pGS655 & $\begin{array}{l}\text { pGS642 with a -T- to -C- change of bp }+79 \text { in } g c v B \\
\left(g c v B^{111+79 C}\right)\end{array}$ & This study \\
\hline pGS656 & 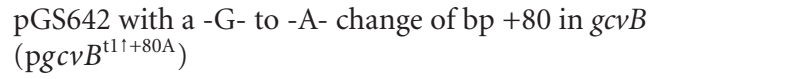 & This study \\
\hline pGS680 & $\begin{array}{l}\text { pGS594 with a deletion from bp }+74 \text { to }+82 \text { in } g c v B \\
\left(\operatorname{pgcvB} B^{\Delta+74: 82}\right)\end{array}$ & This study \\
\hline pGS682 & $\begin{array}{l}\text { pGS680 with a -TG- to -CA- change of bps }+142 \text { and }+143 \text { in } \\
g c v B\left(p g c v B^{\Delta+74: 82+142 \mathrm{CA}}\right)\end{array}$ & This study \\
\hline pGS683 & $\begin{array}{l}\text { pGS680 with a -TG- to -CC- change of bps }+159 \text { and }+160 \text { in } \\
g c v B\left(p g c v B^{\Delta+74: 82+159 C C}\right)\end{array}$ & This study \\
\hline pGS684 & $\begin{array}{l}\text { pGS680 with a -TT- to -CC- change of bps }+131 \text { and }+132 \text { in } \\
g c v B\left(p g c v B^{\Delta+74: 82+131 C C}\right)\end{array}$ & This study \\
\hline pGS688 & pGS680 with the $g c v B^{\mathrm{t} 1 \uparrow}$ change $\left(\mathrm{p} g c v B^{\mathrm{t} 1 \uparrow \Delta+74: 82}\right)$ & This study \\
\hline pGS697 & $\begin{array}{l}\text { pGS680 with a -TG- to -CA- change of bps }+142 \text { and }+143 \\
\text { and a -TG- to -CC- change of bps }+159 \text { and }+160 \text { in } g c v B \\
\left(\mathrm{pgcvB} B^{\Delta+74: 82+142 \mathrm{CA}+159 \mathrm{CC})}\right.\end{array}$ & This study \\
\hline pGS698 & $\begin{array}{l}\text { pGS680 with a -TT- to -CC- change of bps }+131 \text { and }+132 \\
\text { and a -TG- to -CA- change of bps }+142 \text { and }+143 \text { in } g c v B \\
\left(\mathrm{pgcvB} B^{\Delta+74: 82+131 \mathrm{CC}+142 \mathrm{CA}}\right)\end{array}$ & This study \\
\hline pGS699 & $\begin{array}{l}\text { pGS680 with a -TT- to -CC- change of bps }+131 \text { and }+132 \\
\text { and a -TG- to CC change of bps }+159 \text { and }+160 \text { in } g c v B \\
\left(\mathrm{pgcv} B^{\Delta+74: 82+131 C C+159 C C}\right)\end{array}$ & This study \\
\hline \multicolumn{3}{|l|}{ Phage } \\
\hline$\lambda \mathrm{gt} 2$ & $\lambda$ cloning vector; $c \mathrm{I} 857$ repressor & {$[18]$} \\
\hline$\lambda c y c A-l a c Z$ & $\lambda$ vector carrying $\mathrm{WT} c y c A-l a c Z$ translational fusion & {$[2]$} \\
\hline$\lambda c y c A^{-24 \mathrm{GG}}-l a c Z$ & $\begin{array}{l}\lambda \text { vector carrying a } c y c A^{-24 \mathrm{GG}}-l a c Z \text { translational fusion with } \\
\text { an -AC- to -GG- change at nts }-24 \text { and }-25\end{array}$ & This study \\
\hline
\end{tabular}


TABle 1: Continued.

\begin{tabular}{clc}
\hline $\begin{array}{l}\text { Strains*, plasmids, and } \\
\text { phage }\end{array}$ & Relevant genotype & Source or reference \\
\hline$\lambda c y c A^{-29 \mathrm{G}}$-lac $Z$ & $\begin{array}{l}\lambda \text { vector carrying a } c y c A^{-29 \mathrm{G}}-\text { lac } Z \text { translational fusion with } \\
\text { an -A- to - G- change at nt }-29\end{array}$ & This study \\
$\lambda c y c A^{-30 \mathrm{~T}}$-lac $Z$ & $\begin{array}{l}\lambda \text { vector carrying a } c y c A^{-39 \mathrm{~T}}-\text { lac } Z \text { translational fusion with a } \\
\text {-C- to - T- change at nt }-30\end{array}$ & This study \\
\hline
\end{tabular}

* All strains also carry the pheA905 thi araD129 rpsL150 relA1 deoC1 flbB5301 ptsF25 rbsR mutations.

** Numbering for $g c v B$ mutations is based on the transcription initiation site as +1 . Numbering for the $c y c A$ fusions and mutations is based on the A residue in the AUG translation initiation codon as +1 with bases upstream assigned negative values.

changes were verified by DNA sequence analysis at the DNA Core Facility of the University of Iowa. The intermediate

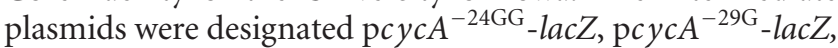
and $\mathrm{p} c y c A^{-30 \mathrm{~T}}$-lacZ. A 5,788 bp EcoRI-MfeI fragment from each plasmid carrying the mutant $c y c A$-lac $Z$ fusions and lacYA genes was then ligated into the EcoRI site of phage $\lambda \mathrm{gt} 2$ [18]. The new phage was designated $\lambda c y c A^{-24 \mathrm{GG}}$-lacZ, $\lambda c y c A^{-29 \mathrm{G}}$-lac $Z$, and $\lambda c y c A^{-30 \mathrm{~T}}$-lac $Z$. The phage were used to lysogenize appropriate $E$. coli host strains as described previously [25]. Each lysogen was tested to ensure that it carried a single copy of the $\lambda$ chromosome by infection with $\lambda c 190 c 17$ [26]. All lysogens were grown at $30^{\circ} \mathrm{C}$ since all fusion phages carry the $\lambda c \mathrm{I} 857$ mutation, resulting in a temperature sensitive $\lambda c \mathrm{I}$ repressor [18].

2.9. RNA Isolation and Northern Analysis. E. coli strains were grown in $5 \mathrm{~mL}$ of LB to mid-log phase. Total RNA was isolated using an RNeasy Mini Kit (Qiagen, Santa Clara, CA) and quantified using a NanoDrop ND-1000 Spectrophotometer. Northern analysis and quantification of RNA were performed as described [13].

\section{Results}

3.1. Nucleotides in GcvB Important for cycA-lacZ Repression. It was suggested that in $S$. enterica several regions in GcvB can independently block translation initiation of $c y c A$ mRNA [6]. To identify any sequence in E. coli GcvB required to regulate $c y c A-l a c Z$, we devised a genetic selection. Since two regions of $G c v B$ from nt +73 to +82 and from +124 to +161 are complementary to $c y c A$ mRNA (Figures 1(b) and $1(\mathrm{c})$ ), we biased the selection by disrupting the primary pairing interactions between GcvB and $c y c A$ mRNA. If both regions are able to pair with $c y c A$ mRNA, disrupting the primary region of interaction would increase the chances of identifying additional nts important for repression. Starting with pGS634 ( $\mathrm{p} g c v B^{+142 \mathrm{CA}+159 \mathrm{CC})}$ as template error-prone PCR was used to mutagenize $g c v B$ [21]. Transformation of a $\triangle g c v B$ strain with the mutagenized DNA allowed us to identify two mutants with increased $c y c A$-lac $Z$ expression (darker blue colonies on X-gal plates). Plasmid DNA prepared from the mutants was sequenced, and two changes in $g c v B$ were identified, a - T- to -C- change at nt +79 and a - Gto -A- change at nt +80 (Figure 1(a), boxed nts). The new plasmids were designated pGS644 (pgcvB $\left.{ }^{+142 C A+159 C C+79 C}\right)$

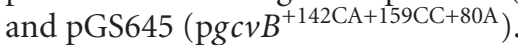

To determine the effects of the mutations on $c y c A-l a c Z$ expression, the $\Delta g c v B \lambda c y c A-l a c Z$ lysogen was transformed with the new plasmids and control plasmid $\mathrm{pgcvB} B^{+}$and assayed for $\beta$-galactosidase. $\beta$-galactosidase levels were 2 fold higher in the $\Delta g c v B$ lysogen compared to WT and repression was restored in the $\Delta g c v B\left[\mathrm{pgcvB}^{+}\right]$transformant (Figure 3(a), lanes 1, 2, and 3). In addition, as reported [2], the pgcvB $B^{+142 \mathrm{CA}+159 \mathrm{CC}}$ allele repressed $c y c A-$ lac $Z$ as well as WT $g c v B^{+}$(Figure 3(a), lane 4). In the presence of the p $c v B^{+142 C A+159 C C+79 C}$ and $p g c v B^{+142 C A+159 C C+80 A}$ alleles, $\beta-$ galactosidase levels were about 2 -fold higher than in the control strains (Figure 3(a), compare lanes 3 and 4 with lanes 5 and 6). Of interest, changes at +79 and +80 (although different nts than the $+79 \mathrm{C}$ and $+80 \mathrm{~A}$ changes) had no effect on $c y c A$-lac $Z$ expression in the absence of the $g c v B^{+142 \mathrm{CA}+159 \mathrm{CC}}$ mutation [2], suggesting both regions must be altered to see a loss of $\mathrm{GcvB}$ repression.

To determine if each $g c v B$ allele produced comparable levels of GcvB, a Northern analysis was performed. The results showed about the same levels of GcvB for each RNA sample tested except the $g c v B^{+142 C A+159 C C}$ allele, which had about $60 \%$ of the WT level (Figure 3(b)). However, the $g c v B^{+142 \mathrm{CA}+159 \mathrm{CC}}$ allele showed normal repression of $c y c A$ lacZ (Figure 3(a), lane 4). Thus, loss of repression for the $g c v B^{+142 \mathrm{CA}+159 \mathrm{CC}+79 \mathrm{C}}$ and $g c v B^{+142 \mathrm{CA}+159 \mathrm{CC}+80 \mathrm{~A}}$ alleles is not due to reduced levels of the mutant RNAs.

3.2. Sequence Preceding Terminator t1 Is Able to Repress $c y c A-l a c Z$. One possibility that could explain the above results is either region of $\mathrm{GcvB}$ complementary to the $c y c A$ mRNA is sufficient to cause repression and both regions must be changed to see an effect. Two experiments provide results that support this hypothesis. Two Rhoindependent terminator sequences can be found in $\operatorname{gcv} B$ centered at $\mathrm{bp}+121$ and $+189 / 190$, designated $\mathrm{t} 1$ and $\mathrm{t} 2$, respectively (Figure 1(a)) [1]. Although in vivo and in vitro evidence suggests some termination occurs at t1 [1], no short transcript was detected in either E. coli or S. enterica by Northern analysis $[5,13]$. We constructed a $g c v B$ allele where $\mathrm{t} 1 \mathrm{is}$ a better Rho-independent terminator $\left(g c v B^{\mathrm{t} 1 \uparrow}\right)$ (Figure 2(a)). If either region of GcvB complementary to $c y c A$ mRNA can pair with the mRNA to cause repression, elimination of sequence distal to t1 should still result in repression of $c y c A-l a c Z$. To ensure any regulation observed is not due to read-through of the $g c v B^{\text {tl }}$ allele, all sequence following $\mathrm{t} 1 \mathrm{was}$ deleted (see Materials and Methods). A 


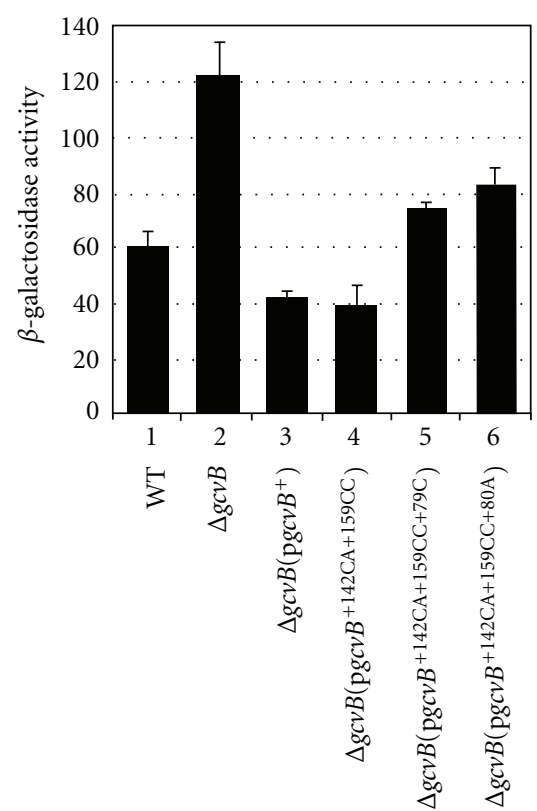

(a)

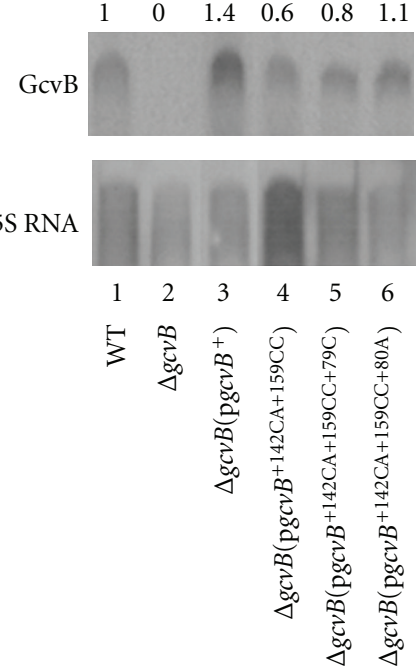

(b)

FIGURE 3: (a) Effects of $g c v B$ mutant alleles on $c y c A$-lacZ expression. WT and $\Delta g c v B \lambda c y c A$-lacZ lysogens transformed with the indicated $g c v B$ alleles were grown in LB (+Amp for transformants) to mid-log phase and assayed for $\beta$-galactosidase. (b) Northern analysis of GcvB. RNA was isolated from WT, $\Delta g c v B$, or $\Delta g c v B$ transformed with the indicated $g c v B$ alleles and probed with either a DIG-labeled GcvB or 5S rRNA specific DNA probe. Numbers above each lane indicate levels of GcvB relative to WT.

Northern Blot showed the $g c v B^{\text {t1 } 1}$ allele produced only a short RNA of $\sim 134$ nts and at levels about $80 \%$ of the WT level (Figure 2(b)). Thus, any change in regulation of $c y c A$ lac $Z$ is likely due to the short RNA rather than a change in the synthesis or stability of the RNA. $\beta$-Galactosidase levels were 2.4-fold higher in the $\Delta g c v B$ lysogen compared to WT, and repression was restored in the $\Delta g c v B\left[\mathrm{pgcv} B^{+}\right]$complemented strain (Figure 4, compare lanes 1, 2, and 3). The $g c v B^{\text {t1t }}$ allele showed $\sim 1.5$-fold better repression of $c y c A$-lac $Z$ than the WT $g c v B$ allele (Figure 4, lanes 3 and 4 ). Although the change was small, it is statistically significant $(P$ value $=0.02$ relative the $\mathrm{pgcvB} B^{+}$transformant). The results suggest the region distal to terminator $\mathrm{t} 1$ is not necessary for GcvB repression of $c y c A$ lacZ.

Next, we introduced the $+79 \mathrm{C}$ and $+80 \mathrm{~A}$ changes, as well as several other changes that do not alter $c y c A-l a c Z$ expression in the full length $\mathrm{GcvB}$, into the $g c v B^{\mathrm{t} 1 \mathrm{t}}$ allele. The +79C (brown), +80A (purple), +76AAA (green), and +79CCCA (blue) changes reduce complementarity of GcvB with $c y c A$ mRNA (Figure 1(c)) and resulted in reduced repression of $c y c A$-lac $Z$ when combined with the $g c v B^{\text {t1 }}$ allele (Figure 4(a), compare lane 4 with lanes 5-8). The +71 CCC change (black) increases complementarity between GcvB and $c y c A$ mRNA (Figure 1(c)) and resulted in 1.3-fold increased repression (Figure 4(a), compare lanes 4 and 9). Although the change is small, it is statistically significant ( $P$ value $=0.005$ relative to the $\mathrm{p} g c v B^{\mathrm{t} 1 \mathrm{t}}$ transformant $)$. A Northern analysis showed about the same amounts of GcvB for each of the RNA samples tested (Figure 4(b)), suggesting altered regulation is not due to altered levels of the mutant
RNAs. The results show the region from +70 to +90 is sufficient for GcvB regulation of $c y c A-l a c Z$, but changes in this region only result in altered regulation if the region distal to $\mathrm{t} 1$ is changed or deleted.

3.3. The $g_{c v B}{ }^{t 11}$ Allele Is Dependent on Hfq. It is possible that the truncated GcvB is able to regulate independently of Hfq. To test this possibility, we transformed the $\Delta h f q$ strain with $\mathrm{phfq}{ }^{3+}, \mathrm{p} g c v B^{+}$, and $\mathrm{p} g c v B^{\mathrm{t} 1+}$ alleles and assayed for $\beta$-galactosidase activity. As shown previously [2], the $\Delta h f q \lambda c y c A-l a c Z$ lysogen showed high levels of $\beta$ galactosidase activity and repression was restored in the $\Delta h f q\left[\mathrm{phfq}{ }^{3+}\right]$ complemented strain (Figure 4(a), lanes 10 and 11). Both the $\Delta h f q\left[\mathrm{pgcv} B^{+}\right]$and $\Delta h f q\left[\mathrm{p} g c v B^{\text {t1 }}\right]$ transformants showed high levels of $\beta$-galactosidase activity, suggesting the truncated $\mathrm{GcvB}$ still requires $\mathrm{Hfq}$ for repression of cycA-lacZ (Figure 4(a), lanes 12 and 13). The results indicate that the Hfq-binding site for GcvB occurs in the region preceding terminator $\mathrm{t} 1$.

3.4. Sequence Distal to Terminator 11 Is Able to Repress cycAlac $Z$. To determine if the region distal to terminator $t 1$ is able to repress $c y c A-l a c Z$, we constructed the $g c v B^{\Delta+74: 82}$ allele. This mutation removes the region of $\mathrm{GcvB}$ that precedes terminator t1 (Figure 1(c)) and shown above to play a role in regulation of $c y c A$-lac $Z$ in the presence of the $g c v B^{\text {tl }} \uparrow$ allele (Figure 4(a)). Despite the size of the deletion, the mfold program $[23,24]$ predicts the remaining secondary structure of GcvB to remain intact. The $g c v B^{\Delta+74: 82}$ allele showed 


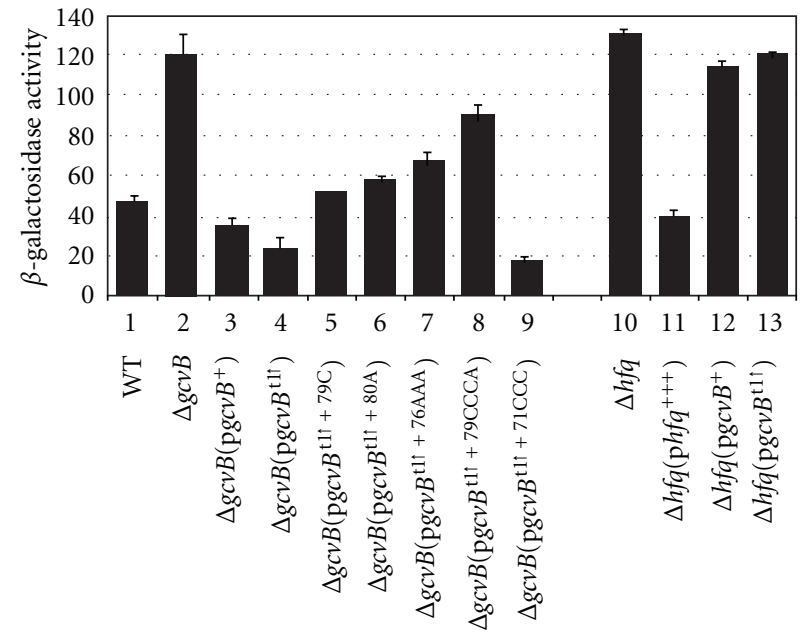

(a)

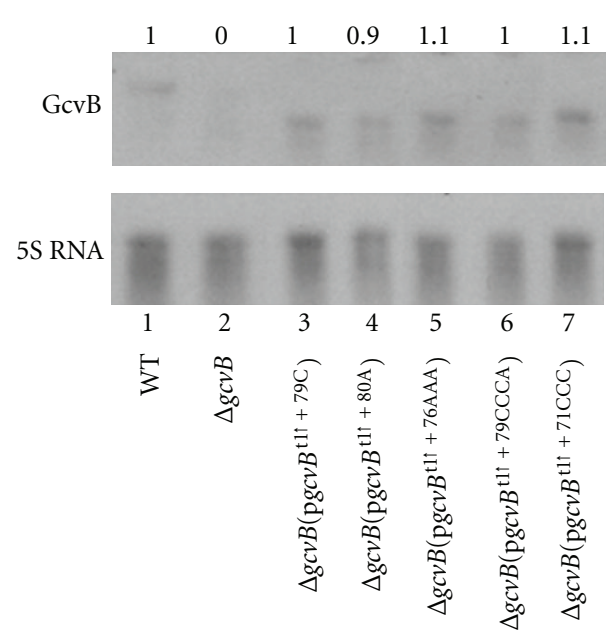

(b)

FIgURE 4: (a) Effects of the $g c v B^{\text {tl }}$ allele plus additional changes on $c y c A$-lacZ expression. WT, $\Delta g c v B$ and $\Delta h f q \lambda c y c A$-lacZ lysogens transformed with the indicated plasmids were grown in LB (+Amp for transformants) to mid-log phase and assayed for $\beta$-galactosidase. (b) Northern analysis of GcvB. RNA was isolated from WT, $\Delta g c v B$ or $\Delta g c v B$ transformed with the indicated plasmids and probed with either a DIG-labeled GcvB or 5S rRNA specific DNA probe. Numbers above each lane indicate levels of GcvB relative to WT.

1.8-fold better repression of $c y c A$-lacZ than WT $g c v B^{+}$ (Figure 5(a), compare lanes 1 and 4). Next, we introduced the +131CC, +142CA and +159CC changes that do not alter $c y c A-l a c Z$ expression in the full length GcvB [2], as well as combinations of these changes, into the $g c v B^{\Delta+74: 82}$ allele. The $g c v B^{\Delta+74: 82+131 C C}$ and $g c v B^{\Delta+74: 82+142 C A+159 C C}$ mutations resulted in $>2$-fold higher levels of expression than the $g c v B^{\Delta+74: 82}$ mutation (Figure 5(a), compare lane 4 with 5 and 10). The remaining mutations showed smaller but statistically significant increases in expression compared to the $g c v B^{\Delta+74: 82}$ allele (Figure 5(a), compare lane 4 with lanes 6-9; $P$ values of $0.036,0.027,0.004$, and 0.014 , resp.). A Northern analysis showed about the same levels of GcvB for each RNA sample tested (Figure 5(b)). The results suggest loss of repression or increased repression is not due to altered levels of the mutant RNAs.

We also combined the $g c v B^{\Delta+74: 82}$ mutation with the $g c v B^{\text {tl } 1}$ allele. However, a Northern analysis of two separate RNA preparations from a strain carrying the $\mathrm{p} g c v B^{\mathrm{t} 11 \Delta+74: 82}$ allele showed only about $30 \%$ of the GcvB level found with $\mathrm{p} g c v B^{+}$. The results suggest the $g c v B^{\mathrm{t} 1 \uparrow \Delta+74: 82}$ is unstable and was not pursued further.

3.5. Regulation Requires $G c v B / C y c A$ mRNA Interactions. To confirm altered regulation is due to altered $\mathrm{GcvB} / \mathrm{cycA}$ mRNA interactions, we constructed a $\lambda c y c A^{-24 \mathrm{GG}}$-lac $Z$ fusion (an -AC- to -GG- change at nts $-24,-25$ relative to the $c y c A$ AUG start site); the changes reduce paring of $c y c A$ mRNA with both regions of GcvB complementary to $c y c A$ (Figures 1(b) and 1(c)). We also constructed $\lambda c y c A^{-29 G}$ lac $Z$ and $\lambda c y c A^{-30 \mathrm{~T}}$-lac $Z$ fusions (an -A- to -G- change at nt -29 and a $-\mathrm{C}$ - to $-\mathrm{T}$ - change at $\mathrm{nt}-30$ relative to the $c y c A$ AUG start site, resp.); the changes reduce pairing of $c y c A$ mRNA with the +73 to +82 region of GcvB (Figures 1 (b) and 1(c)). A WT $\lambda c y c A^{-24 \mathrm{GG}}$-lacZ lysogen had $\sim 5.5$-fold lower levels of expression than the WTגcycA-lacZ lysogen, suggesting the -GG- change affects translation efficiency (Figure 6, compare lines 1 and 14). The WT $\lambda c y c A^{-24 \mathrm{GG}}$-lacZ and $\Delta g c v B \lambda c y c A^{-24 \mathrm{GG}}$-lac $Z$ lysogens, as well as $\mathrm{p} g c v B^{+}$and $\mathrm{p} g c v B^{\Delta+74: 82}$ complemented lysogens, showed essentially the same levels of expression, suggesting a complete loss of GcvB regulation (Figure 6, lines 14, 15, 16, and 18). However, the $\mathrm{p} g c v B^{+159 C \mathrm{C}}$ and $\mathrm{p} g c v B^{+74: 82+159 \mathrm{CC}}$ alleles, that restore pairing with the $c y c A^{-24 \mathrm{GG}}$ allele, repressed $c y c A^{-24 \mathrm{GG}}$-lac $Z$ expression about 1.5-fold (Figure 6, compare line 14 with lines 17 and 19). Although the changes are less than the normal 2-fold repression observed for $c y c A$ by $\mathrm{GcvB}$, the results are statistically significant $(P$ values of 0.0001 and 0.0028 relative to the $\mathrm{WT} \lambda c y c A^{-24 \mathrm{GG}}$ lysogen, resp.) and suggest pairing of $\mathrm{GcvB}$ in the +124 to +161 region with $c y c A$ mRNA is required for repression.

The WT $\lambda c y c A^{-29 \mathrm{G}}$-lac $Z$ and $\lambda c y c A^{-30 \mathrm{~T}}$-lac $Z$ lysogens showed levels of expression similar to the WT $\lambda$ cycA-lac $Z$ lysogen, suggesting the changes do not dramatically affect translation efficiency (Figure 6, compare lane 1 with lanes 4 and 9). In addition, $\beta$-galactosidase levels were about 2 fold higher in each $\triangle g c v B$ lysogen compared to its WT control and repression was restored in the $\Delta g c v B\left[\mathrm{pgcvB} B^{+}\right]$ and $\Delta g c v B\left[\mathrm{pgcv} B^{\mathrm{t} 1 \uparrow}\right]$ transformants (Figure 6, compare lanes 4-7 and lanes 9-12). This is not unexpected since the $c y c A^{-29 \mathrm{G}}$ and $c y c A^{-30 \mathrm{~T}}$ changes disrupt pairing with GcvB in the +73 to +82 region but do not disrupt pairing in the +124 to +161 region (Figures $1(\mathrm{~b})$ and $1(\mathrm{c})$ ). However, the $\mathrm{p} g c v B^{\mathrm{t} 1 \uparrow+79 \mathrm{C}}$ and $\mathrm{p} g c v B^{\mathrm{t} 1 \uparrow+80 \mathrm{~A}}$ alleles, that restore 


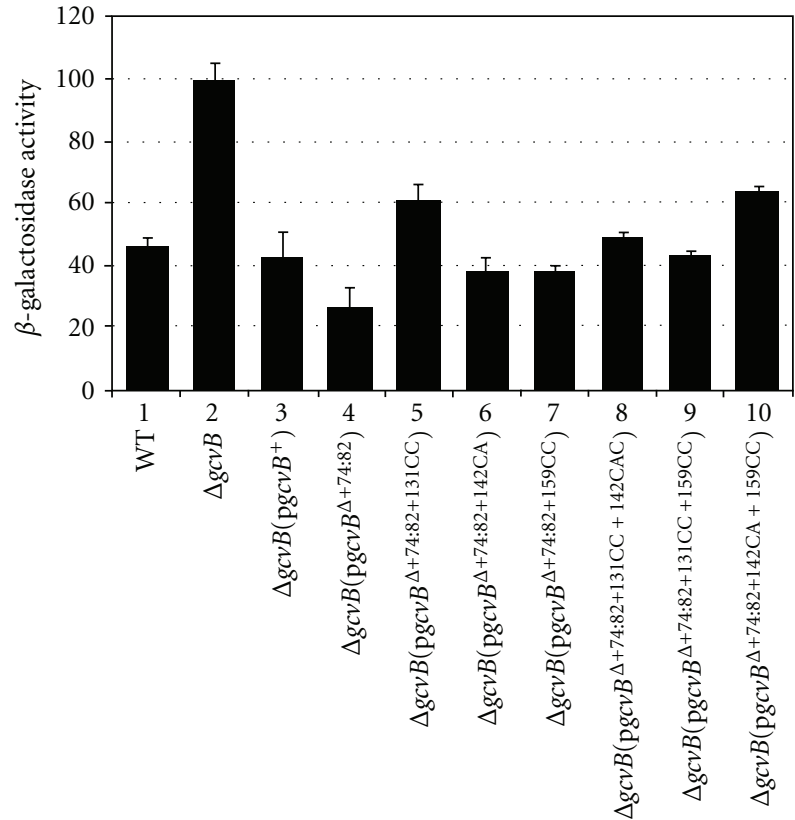

(a)

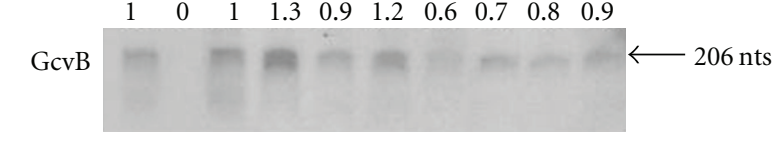

5S RNA

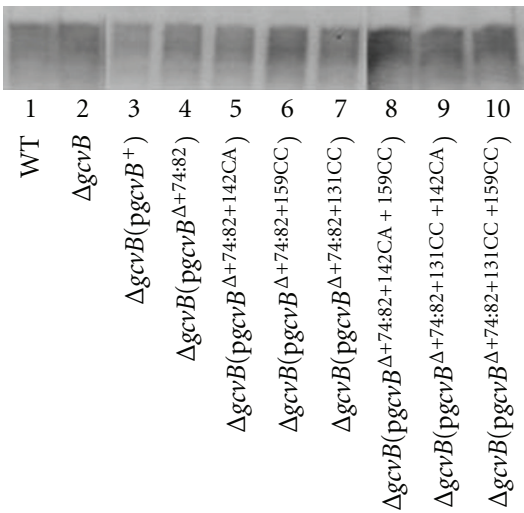

(b)

Figure 5: (a) Effects of the $g c v B^{\Delta+74: 82}$ allele plus additional mutations on $c y c A$-lacZ expression. WT and $\Delta g c v B \lambda c y c A$-lacZ lysogens transformed with the indicated plasmids were grown in LB (+Amp for transformants) to mid-log phase and assayed for $\beta$-galactosidase. (b) Northern analysis of GcvB. RNA was isolated from WT, $\Delta g c v B$, or $\Delta g c v B$ transformed with the indicated plasmids and probed with either a DIG-labeled GcvB or $5 \mathrm{~S}$ rRNA-specific DNA probe. Numbers above each lane indicate levels of GcvB relative to WT.

pairing with the $c y c A^{-29 \mathrm{G}}$ and $c y c A^{-30 \mathrm{~T}}$ alleles, respectively, increased repression an additional 2-fold (Figure 6, compare lanes 4 and 8 and lanes 9 and 13). The results suggest pairing of $\mathrm{GcvB}$ in the +73 to +82 region with $c y c A$ mRNA is also required for repression. The above results are in agreement with a model of genetic redundancy as a mechanism for $c y c A$ regulation by E. coli GcvB.

\section{Discussion}

In E. coli and S. enterica, GcvB has been shown to regulate multiple genes involved in amino acid and peptide transport [1-6]. However, most changes in $\mathrm{GcvB}$ predicted to disrupt pairing with target mRNAs had no significant effect on GcvB-mediated repression [2-4]. For the $c y c A$ mRNA, GcvB shows 2 regions of complementarity (Figures $1(\mathrm{~b})$ and $1(\mathrm{c}))$. In this study, we tested if either region of complementarity is able to independently repress $c y c A-l a c Z$. The $g c v B^{t 1 t}$ allele produces a truncated GcvB of $\sim 134 \mathrm{nts}$ and would remove most of the region from nt +124 to +161 complementary with $c y c A$ mRNA (Figure 1(a)). The $g c v B^{\text {t1 }}$ allele showed better repression of $c y c A$-lacZ than WT $g c v B$ (Figure 4, lanes 3 and 4). The results suggest the region distal to terminator $\mathrm{t} 1$ is not necessary for repression of $c y c A-l a c Z$ and possibly prevents full repression by GcvB. Mutations in $g c v B$ in the +76 to +82 region that reduce complementarity with $c y c A$ mRNA (Figure 1(c)) result in a significant loss of repression in the presence of the $g c v B^{\mathrm{t} 1 \mathrm{t}}$ mutation (Figure 4, compare lane 4 with lanes 5-8), and a change at nts +71 to +73 that increases complementarity results in increased repression (Figure 4, compare lanes 4 and 9). These results suggest the region of complementarity preceding terminator $\mathrm{tl}$ is responsible for repression in the $g c v B^{\text {t1 } 1}$ background. Of interest, these mutations do not alter GcvB repression in the full-length molecule [2]. The $g_{c} v B^{\Delta+74: 82}$ allele, which removes the region of GcvB preceding terminator $\mathrm{t} 1$ involved in repression in the $g c v B^{\mathrm{tl} 1}$ background (Figure 1(c)), also showed better repression of $c y c A$-lac $Z$ than WT $g c v B$ (Figure 5(a), compare lanes 3 and 4). Thus, when the region of GcvB distal to terminator $t 1$ is intact, the region of $\mathrm{GcvB}$ in the +74 to +82 region is not required for repression and appears to partially inhibit repression. Mutations in $g c v B$ in the +131 to +160 region that do not alter GcvB repression in the full length GcvB [2] result in a significant loss of repression in the presence of the $g c v B^{+74: 82}$ mutation (Figure 5(a), compare lane 4 with lanes $5-10)$. These results suggest the region of complementarity following terminator $\mathrm{t} l$ is responsible for repression in the $g c v B^{\Delta+74: 82}$ background. Several of the mutations change the Con-II sequence (Figure 1(b)). However, other changes that result in a loss of repression fall outside of this region. Thus, although the Con-II sequence is likely involved in regulation of $c y c A$, additional sequence is also required. In many bacteria, multiple largely redundant sRNAs control identical target mRNAs [27, 28]. In addition, a single sRNA can regulate many genes $[29,30]$. Although most sRNAs use one region for basepairing, a few use independent regions to basepair with different target mRNAs. For example, two regions of DsrA are necessary for full activity on the hns 


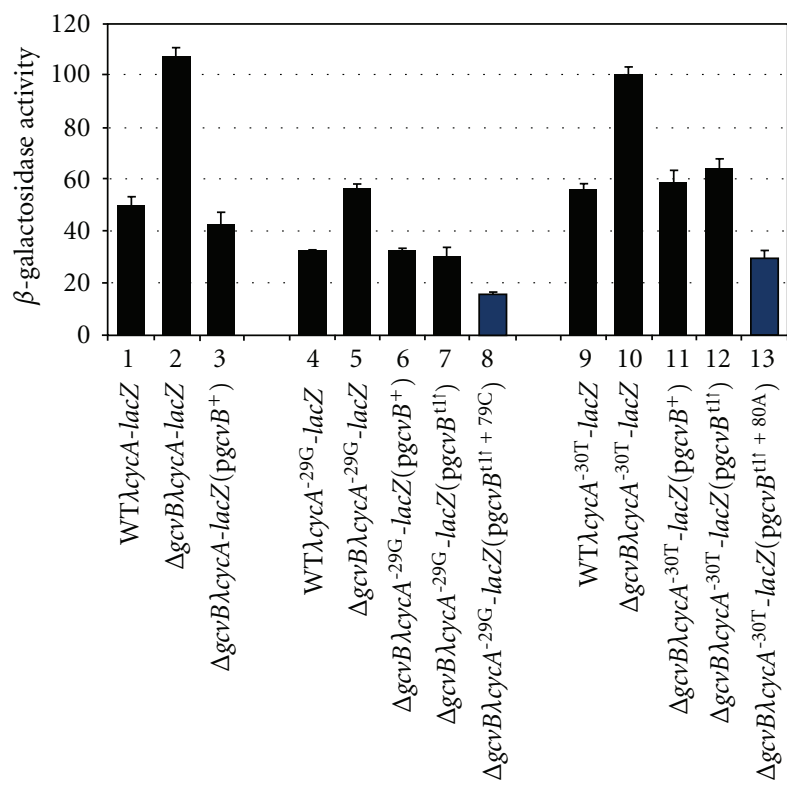

(a)

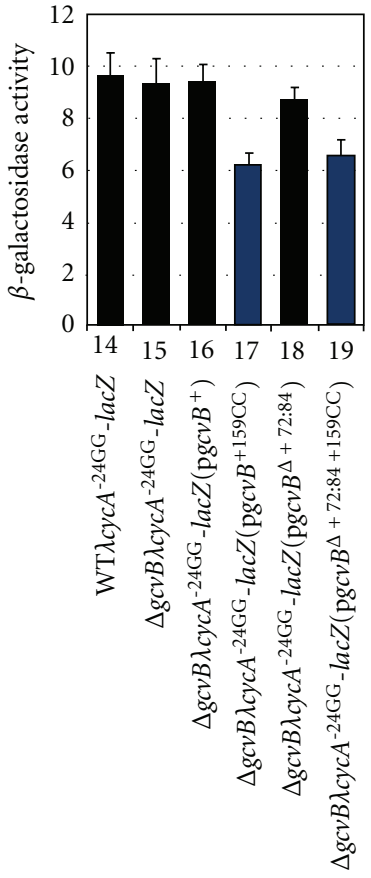

(b)

Figure 6: GcvB represses $c y c A$ mRNA by an antisense mechanism. WT and $\Delta g c v B \lambda c y c A-l a c Z, \lambda c y c A^{-29 G}-l a c Z, \lambda c y c A^{-30 T}-l a c Z$, and $\lambda c y c A^{-24 \mathrm{GG}}-$ lac $Z$ lysogens transformed with the indicated plasmids were grown in LB (+Amp for transformants) to mid-log phase and assayed for $\beta$-galactosidase.

and rpoS mRNAs [31, 32] and two different regions of FnrS basepair with different sets of target mRNAs [33]. The results in this study show that 2 regions of GcvB complementary with the same region of the $c y c A$ mRNA are able to independently basepair with the $c y c A$ mRNA and repress expression by an antisense mechanism. In addition, the results open the possibility that GcvB can bind simultaneously and repress two different mRNA molecules.

Of interest, none of the mutations in the presence of the t1 $\uparrow$ allele or the $\Delta+74: 82$ allele resulted in a complete loss of GcvB repression of the $c y c A$-lac $Z$ fusion (Figures 4 and 5(a)). An examination of each mutant allele identified small regions that could still basepair with the $c y c A$ mRNA (not shown). If these small regions are involved in the repression observed, the results would suggest a high degree of flexibility in GcvB basepairing with target mRNAs. S. enterica GcvB also shows several redundant pairing regions with $c y c A$, and in vitro experiments suggest several regions of GcvB independently inhibit translation initiation of $c y c A$ mRNA [6]. Thee results suggest genetic redundancy is a mechanism for regulation by GcvB.

Since many of the genes that respond to GcvB are involved in transport of small peptides and amino acids, we hypothesize this is a survival mechanism to turn down transporters under conditions that favor the presence of toxic molecules that are also transported by these systems [2]. Another class of genes regulated by GcvB is involved in acid resistance (unpublished results) [34], suggesting GcvB plays a role in E. coli survival at low $\mathrm{pH}$. Both of these environmental stresses would be encountered as E. coli moves from an external environment into the GI tract. We hypothesize the functions of the genes regulated by $\mathrm{GcvB}$ are crucial to cell survival when cells colonize the GI tract and the redundancy in GcvB prevents accidental loss of regulation of these genes by mutation or possible changes in $\mathrm{GcvB}$ structure induced by environmental conditions.

\section{Acknowledgments}

This work was supported by Public Health Service Grant GM069506 from the National Institute of General Medical Sciences and the Vice President for Research, the Carver College of Medicine and the Department of Microbiology, University of Iowa.

\section{References}

[1] M. L. Urbanowski, L. T. Stauffer, and G. V. Stauffer, "The gcvB gene encodes a small untranslated RNA involved in expression of the dipeptide and oligopeptide transport systems in Escherichia coli," Molecular Microbiology, vol. 37, no. 4, pp. 856-868, 2000.

[2] S. C. Pulvermacher, L. T. Stauffer, and G. V. Stauffer, "Role of the sRNA GcvB in regulation of cycA in Escherichia coli," Microbiology, vol. 155, no. 1, pp. 106-114, 2009.

[3] S. C. Pulvermacher, L. T. Stauffer, and G. V. Stauffer, "The role of the small regulatory RNA GcvB in GcvB/mRNA posttranscriptional regulation of oppA and dppA in Escherichia coli," FEMS Microbiology Letters, vol. 281, no. 1, pp. 42-50, 2008. 
[4] S. C. Pulvermacher, L. T. Stauffer, and G. V. Stauffer, "The small RNA GcvB regulates sstT mRNA expression in Escherichia coli," Journal of Bacteriology, vol. 91, no. 1, pp. 238248, 2009.

[5] C. M. Sharma, F. Darfeuille, T. H. Plantinga, and J. Vogel, "A small RNA regulates multiple ABC transporter mRNAs by targeting C/A-rich elements inside and upstream of ribosomebinding sites," Genes and Development, vol. 21, no. 21, pp. 2804-2817, 2007.

[6] C. M. Sharma, K. Papenfort, S. R. Pernitzsch, H. J. Mollenkopf, J. C. D. Hinton, and J. Vogel, "Pervasive post-transcriptional control of genes involved in amino acid metabolism by the Hfq-dependent GcvB small RNA," Molecular Microbiology, vol. 81, no. 5, pp. 1144-1165, 2011.

[7] S. Gottesman, "The small RNA regulators of Escherichia coli: roles and mechanisms," Annual Review of Microbiology, vol. 58, pp. 303-328, 2004.

[8] H. Aiba, "Mechanism of RNA silencing by Hfq-binding small RNAs," Current Opinion in Microbiology, vol. 10, no. 2, pp. 134-139, 2007.

[9] R. G. Brennan and T. M. Link, "Hfq structure, function and ligand binding," Current Opinion in Microbiology, vol. 10, no. 2, pp. 125-133, 2007.

[10] P. Valentin-Hansen, M. Eriksen, and C. Udesen, "The bacterial Sm-like protein Hfq: a key player in RNA transactions," Molecular Microbiology, vol. 51, no. 6, pp. 1525-1533, 2004.

[11] A. Zhang, K. M. Wassarman, C. Rosenow, B. C. Tjaden, G. Storz, and S. Gottesman, "Global analysis of small RNA and mRNA targets of Hfq," Molecular Microbiology, vol. 50, no. 4, pp. 1111-1124, 2003.

[12] A. Sittka, S. Lucchini, K. Papenfort et al., "Deep sequencing analysis of small noncoding RNA and mRNA targets of the global post-transcriptional regulator, Hfq," PLoS Genetics, vol. 4, no. 8, Article ID e1000163, 2008.

[13] S. C. Pulvermacher, L. T. Stauffer, and G. V. Stauffer, "Role of the Escherichia coli Hfq protein in GcvB regulation of oppA and dppA mRNAs," Microbiology, vol. 155, no. 1, pp. 115-123, 2009.

[14] H. Kawamoto, Y. Koide, T. Morita, and H. Aiba, "Basepairing requirement for RNA silencing by a bacterial small RNA and acceleration of duplex formation by Hfq," Molecular Microbiology, vol. 61, no. 4, pp. 1013-1022, 2006.

[15] R. L. Wilson and G. V. Stauffer, "DNA sequence and characterization of GcvA, a LysR family regulatory protein for the Escherichia coli glycine cleavage enzyme system," Journal of Bacteriology, vol. 176, no. 10, pp. 2862-2868, 1994.

[16] R. L. Wilson, M. L. Urbanowski, and G. V. Stauffer, "DNA binding sites of the LysR-type regulator GcvA in the $\mathrm{gcv}$ and gcvA control regions of Escherichia coli," Journal of Bacteriology, vol. 177, no. 17, pp. 4940-4946, 1995.

[17] A. D. Jourdan and G. V. Stauffer, "Mutational analysis of the transcriptional regulator GcvA: amino acids important for activation, repression, and DNA binding," Journal of Bacteriology, vol. 180, no. 18, pp. 4865-4871, 1998.

[18] S. M. Panasenko, J. R. Cameron, R. W. Davis, and I. R. Lehman, "Five hundredfold overproduction of DNA ligase after induction of a hybrid lambda lysogen constructed in vitro," Science, vol. 196, no. 4286, pp. 188-189, 1977.

[19] J. Miller, Experiments in Molecular Genetics, Cold Spring Harbor Laboratory Press, Cold Spring Harbor, NY, USA, 1972.

[20] H. J. Vogel and D. M. Bonner, "Acetylornithinase of Escherichia coli: partial purification and some properties.", The Journal of Biological Chemistry, vol. 218, no. 1, pp. 97-106, 1956.
[21] Y. Zhou, X. Zhang, and R. H. Ebright, "Random mutagenesis of gene-sized DNA molecules by use of PCR with Taq DNA polymerase," Nucleic Acids Research, vol. 19, no. 21, p. 6052, 1991.

[22] G. Sarkar and S. S. Sommer, "The 'megaprimer' method of site-directed mutagenesis," BioTechniques, vol. 8, no. 4, pp. 404-407, 1990.

[23] D. H. Mathews, J. Sabina, M. Zuker, and D. H. Turner, "Expanded sequence dependence of thermodynamic parameters improves prediction of RNA secondary structure," Journal of Molecular Biology, vol. 288, no. 5, pp. 911-940, 1999.

[24] M. Zuker, "Mfold web server for nucleic acid folding and hybridization prediction," Nucleic Acids Research, vol. 31, no. 13, pp. 3406-3415, 2003.

[25] M. L. Urbanowski and G. V. Stauffer, "Autoregulation by tandem promoters of the Salmonella typhimurium LT2 metJ gene," Journal of Bacteriology, vol. 165, no. 3, pp. 740-745, 1986.

[26] K. Shimada, R. A. Weisberg, and M. E. Gottesman, "Prophage lambda at unusual chromosomal locations. I. Location of the secondary attachment sites and the properties of the lysogens," Journal of Molecular Biology, vol. 63, no. 3, pp. 483-503, 1972.

[27] K. C. Tu and B. L. Bassler, "Multiple small RNAs act additively to integrate sensory information and control quorum sensing in Vibrio harveyi," Genes and Development, vol. 21, no. 2, pp. 221-233, 2007.

[28] M. Guillier and S. Gottesman, "The $5^{\prime}$ end of two redundant sRNAs is involved in the regulation of multiple targets, including their own regulator," Nucleic Acids Research, vol. 36, no. 21, pp. 6781-6794, 2008.

[29] E. Massé, C. K. Vanderpool, and S. Gottesman, "Effect of RyhB small RNA on global iron use in Escherichia coli," Journal of Bacteriology, vol. 187, no. 20, pp. 6962-6971, 2005.

[30] E. Massé and S. Gottesman, "A small RNA regulates the expression of genes involved in iron metabolism in Escherichia coli," Proceedings of the National Academy of Sciences of the United States of America, vol. 99, no. 7, pp. 4620-4625, 2002.

[31] R. A. Lease and M. Belfort, "Riboregulation by DsrA RNA: Trans-actions for global economy," Molecular Microbiology, vol. 38, no. 4, pp. 667-672, 2000.

[32] N. Majoalani, C. Cunning, D. Sledjeski, T. Elliott, and S. Gottesman, "DsrA RNA regulates translation of RpoS message by an anti-antisense mechanism, independent of its action as an antisilencer of transcription," Proceedings of the National Academy of Sciences of the United States of America, vol. 95, no. 21, pp. 12462-12467, 1998.

[33] S. Durand and G. Storz, "Reprogramming of anaerobic metabolism by the FnrS small RNA," Molecular Microbiology, vol. 75, no. 5, pp. 1215-1231, 2010.

[34] Y. Jin, R. M. Watt, A. Danchin, and J. D. Huang, "Small noncoding RNA GcvB is a novel regulator of acid resistance in Escherichia coli," BMC Genomics, vol. 10, article 165, 2009. 

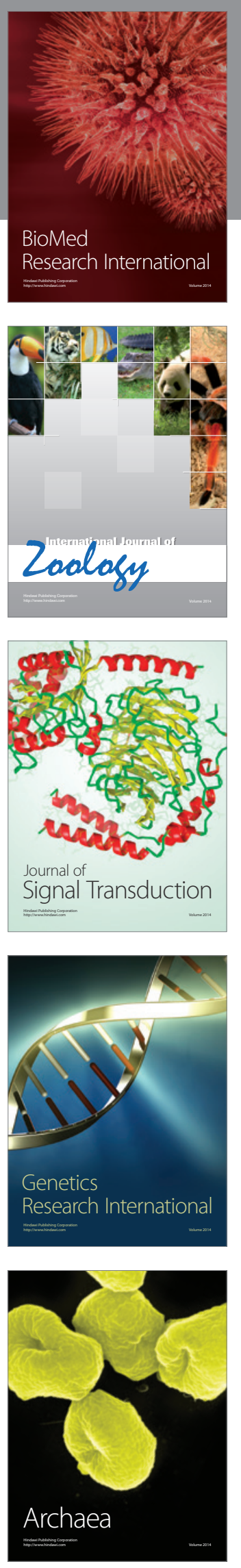
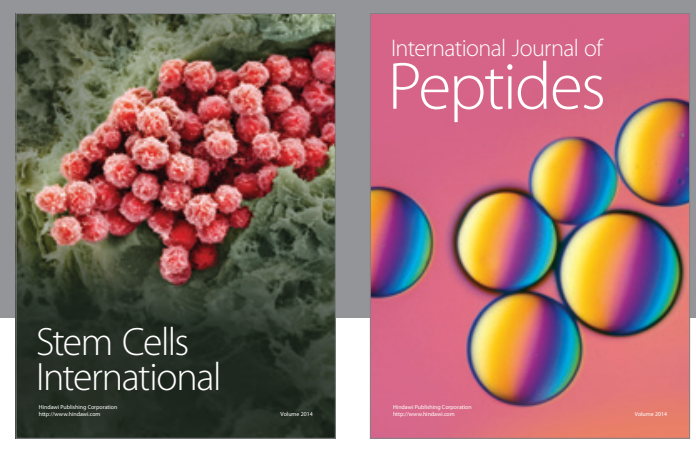

Submit your manuscripts at

http://www.hindawi.com
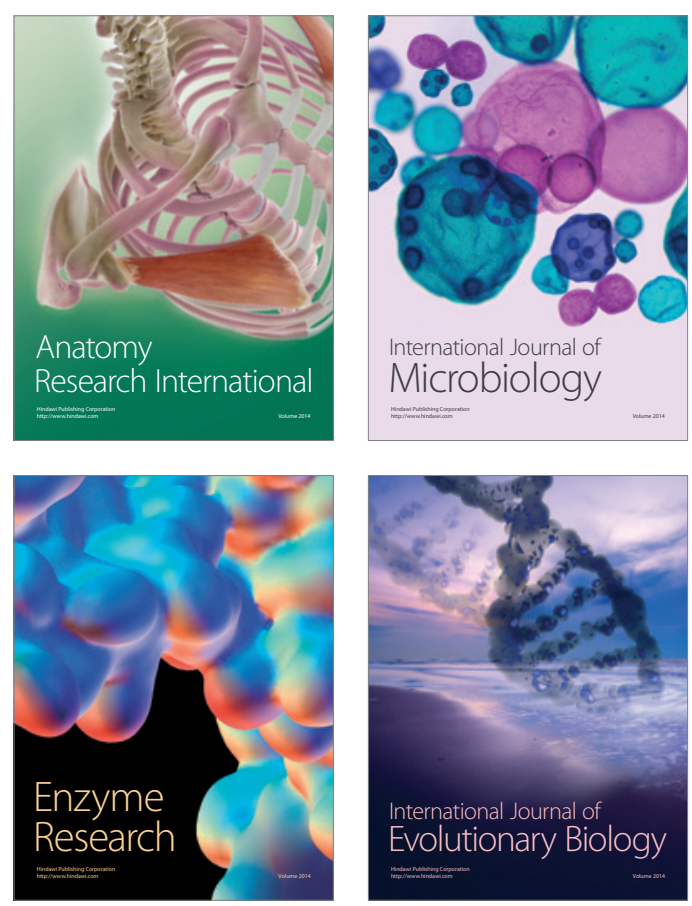
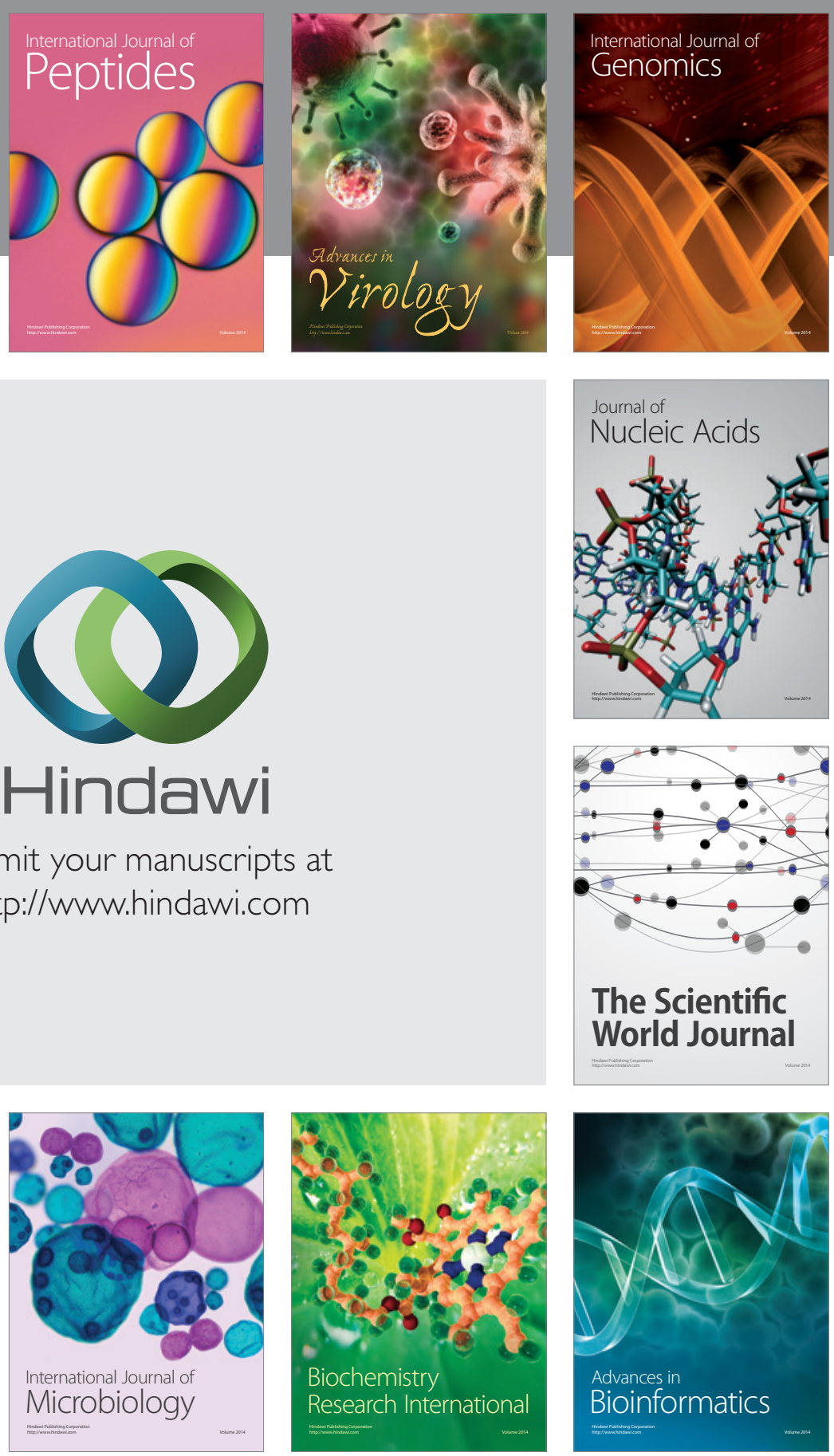

The Scientific World Journal
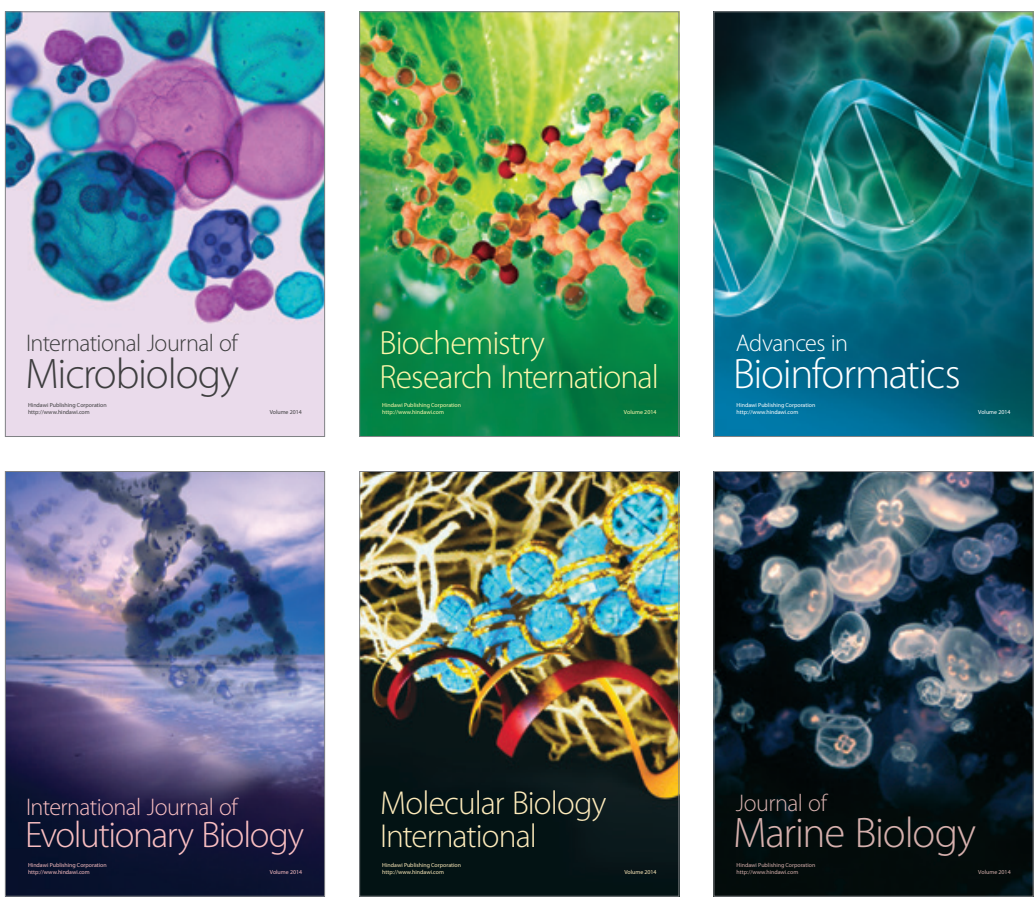